\title{
Splątanie literackie
}

Fizyka już nieraz proponowała wizję świata, którą wykorzystywała nie tylko literatura i sztuka, ale także podejmowały rozmaite dyskursy krytycznoliterackie. Dziać się to mogło na kilka sposobów. Twórczość artystyczna za sprawą inspiracji nowymi odkryciami naukowymi starała się odpowiedzieć na jej wyzwania - zafascynowana teoriami nauk ścisłych czy przyrodniczych - odkrywała w już istniejącym literackim świecie podobne zasady i zbieżne $\mathrm{z}$ nimi lub wyprzedzające je twórcze intuicje. Niekiedy zdarzało się też tak, że zastosowanie nowoczesnej teorii matematycznej nie przekształcało literackiego świata, ale pokazywało nieoczekiwane możliwości określenia związków nauk ścisłych ze sztuką. Wyrazistym przykładem może tu być np. inspiracja teorią chaosu, której nie dało się odnaleźć bezpośrednio w samych kreacjach literackich. Podejmowane próby były w większości nieudane i niepełne. Operowały raczej metaforą niż przeniesieniem mechanizmu działania teorii. Jak się wydaje, doszukiwanie się struktur fraktalnych w literaturze udać się nie mogło przede wszystkim ze względu na naturę języka, który nie jest $\mathrm{w}$ stanie stworzyć struktur samopodobnych, rozumianych zgodnie z matematyczną teorią chaosu. Jednakże teoria zainspirowała badaczy metaforycznym obrazem i zaskakującymi możliwościami ocen estetycznych (sam Benoît B. Mandenlbrot na początku poszukiwań teorii nazywał fraktale fascynującymi brzydotą monstrami, by po ukończeniu prac zobaczyć geometrię fraktalną jako powtarzające się piękne figury). Teoria samopodobieństwa okazała się znów na swój sposób piękna, potwierdzając intuicje Paula Diraca, zachwyconego logiką i estetyką doskonale wyprowadzonego równania matematycznego. Mało tego, niektóre procedury w badaniach literackich opierać się zaczęły na pojęciach z zakresu matematyki, jak słynna już dziś iteracja używana przez Jacques’a Derridę.

Proces wzajemnego doświadczania siebie przez różne nauki uczestniczące we wspólnym przeżywaniu i czytaniu świata trwa od dawna. Jeszcze wczoraj używaliśmy wraz ze strukturalistami terminu $\mathrm{z}$ teorii informacji - entropia, definiując ją jako miarę szumu, zakłócenie w komunikacji. Dziś pojęcie szumu wraca także w opisie stanów kwantowych splątanych cząstek jako element niszczący możliwość odczytania ich stanów. Szum w sztuce zrobił jednak dopiero karierę jako pojęcie dekonstrukcji. Powiedzieć by można, że szum jako materia dźwiękowa związał się z muzyką, fraktale odwołujące się do wrażeń wzrokowych zdominowały plastykę. W literaturze muzyczność i plastyczność, sferę dźwięku i obrazu wykorzystywał - mistrzowsko łącząc te kategorie - np. Miron

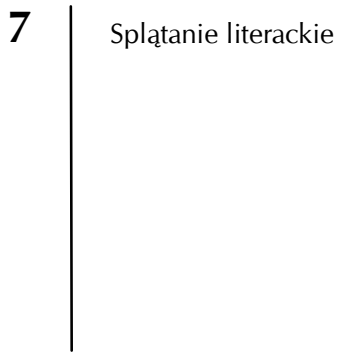


Białoszewski, zapoczątkowując tym samym nowoczesne, łamiące granice sztuk, pisanie performatywne.

Dyskursy literaturoznawcze, zwłaszcza po doświadczeniach dekonstrukcji, przejmują chętnie osiągnięcia zarówno nauk ścisłych, jak i sztuki. Pisząc o literaturze, zaczynamy ją zawsze od początku współtworzyć. Chodzi po pierwsze o proste odniesienie wypowiedzi literaturoznawczej do reguł kształtowania zarezerwowanych do tej pory dla sztuki. Posługując się przykładem najoczywistszym, wymienić trzeba prace Derridy, które się nie tylko czyta, ale i ogląda, które właściwie należałoby rozgrywać performatywnie, tak by z każdą inscenizacją prze(d)stawiać proponowane związki i zależności pojęciowo-obrazowe. Język dyskursu fizyki odsyłał bardzo często do pojęć i nazw bliskich ujęciom metaforycznym, jak „ciemna materia”, „czarne dziury”, nazywał obrazowo paradoksy, jak „kot Schrödingera - równocześnie żywy i martwy". Gdyby przyjrzeć się bliżej dyskursom literaturoznawczym, filozoficznym czy estetycznym odnajdziemy mnóstwo metafor, epitetów, paradoksów, które wytworzyły dość trwałe połączenia (np. Adornowska ciemność absurdu, Kierkegaarda odblask tragedii itp.). W fizykalnych kategoriach estetycznych, jak lekkość czy przejrzystość, opisuje literaturę np. Italo Calvino w Wykładach amerykańskich. Wprowadzając nowe jakości, utrwalając zbitki pojęciowe sprawiamy, że świat zastyga pod naszym spojrzeniem. Już nigdy absurd nie będzie miał jasnej strony (chyba, że ktoś napisze o jasności absurdu...).

Po drugie pisanie o literaturze pojmowane jako jej współtworzenie daje się rozumieć w odniesieniu do co najmniej dwóch procedur - przyjmowania reguł interpretacji i tworzenia wizji historii literatury. To, jak dziś czytamy i komentujemy utwory literackie, wpływa na całą historię literatury. Poruszenie interpretacyjne choćby jednego wiersza przekształca materię literackiej przeszłości. Sposób pisania o literaturze równocześnie zmienia ją samą.

Idąc tym tropem dalej, można by powiedzieć, że tak rozumiane procedury literaturoznawcze wychodzą z podobnej wizji świata, jaką zaproponowała współczesna fizyka w postaci zjawiska nazwanego splątaniem kwantowym.

Splątane cząstki tworzą całość. Nawet rozdzielone, znajdując się w dużej odległości od siebie, zachowują wzajemne zależności - stan jednej wciąż zależy od stanu drugiej. Określając parametry jednej z nich, uzyskujemy równocześnie wiedzę o nich obu jako splątanej całości. Jak zatem wyjaśnić, w jaki sposób cząstki wpływają na siebie? Czym jest rzeczywistość i czy świat istnieje bez związku z naszą świadomością? Jaka jest natura czasu, przestrzeni, jaka jest istota materii, umysłu, świadomości? Pytania odwieczne... 
Fizyka zawsze pozostawała „w stanie splątania” z filozofią. Nie bez znaczenia było zapewne to, że Erwin Schrödinger czy David Bohm interesowali się religiami Wschodu. Stale przekraczając nasze wyobrażenia o świecie, coraz częściej myślimy o zależnościach między świadomością a materią, odrzucając antropocentryczny punkt widzenia, wkraczamy $\mathrm{w}$ erę posthumanizmu, a wraz z nim umacniamy przekonanie o jedności Wszechświata.

Historia literatury tworzy specyficzną całość, niedomkniętą, stale będącą w ruchu, pulsującą, zmienną, redefiniowalną. Fakty literackie nie przylegają do siebie niczym korale nanizane na nić, lecz raczej przypominają punkty wiązań niewidzialnej, nieskończonej sieci. Tak pojęta całość nie stanowi struktury. Jest płynnym, falującym procesem wzajemnych wpływów, nieraz nieprzewidywalnych związków i niedookreślonych zjawisk. Nasze literaturoznawcze procedury interpretacyjne nie muszą wędrować zawsze po kole, stawiając akcenty - a to na autora, a to patrząc z pozycji tekstu bądź ulegając horyzontowi odbiorcy. Nowe rozwiązania w tym zakresie proponuje choćby performatyka, której bliska zapewne byłaby idea kwantowego splątania. Magia czy raczej presja konieczności stałego określania sił podstawowych, podporządkowujących sobie inne podmioty i plany aktu komunikacji, kryjąca w sobie układy hierarchiczne, może być zastąpiona procedurami związanymi z pojęciem - utworzonym na wzór terminu z fizyki kwantowej - splątania literackiego. Jeśli uda się odsunąć wszystkie przeszkody i odrzucić zanieczyszczający, deformujący przekaz szum, w postaci przymusu stosowania binarnych opozycji, hierarchizujących podporządkowań kulturowych, jednoznacznie uprzywilejowanych stanowisk metodologicznych, może uda się zobaczyć historię literatury jako zmienne pole wzajemnych wpływów i powiązań, które nawet oddalone w czasie i przestrzeni elementy ukażą w literackim splątaniu.

Anna Krajewska 